\title{
领的起源: 发育生物学假说与化石实证的交叉
}

\author{
盖志琨，朱敏* \\ 中国科学院古脊椎动物与古人类研究所, 中国科学院脊椎动物进化系统学重点实验室, 北京 100044 \\ * 联系人, E-mail: zhumin@ivpp.ac.cn
}

2012-05-08 收稿, 2012-05-29 接受

国家自然科学基金重点项目(40930208)、国家重点基础研究发展计划(2012CB821902)和中国科学院知识创新工程重要方向项目

(KZCX2-YW-156)资助

\begin{abstract}
摘要 从分子生物学、发育生物学与古生物学等多角度评述了脊椎动物领的起源研究中的 最新进展. 发育遗传学的一系列进展促成了领演化异位理论的提出, 即领的起源, 是在上 皮-外肧层间质细胞相互作用中，由于口腔发育调控基因的异位表达所导致的一次演化上的 创新. 在无领类七鳃鳗的发育过程中，外胚层间质细胞的向前生长由于受到中央鼻垂体板 的阻挡，无法像有领类那样发育成领和频桁。因此，该理论推测鼻垂体复合体的分裂是领 发育的最根本的先决条件, 应该发生在领的起源之前. 鼻垂体复合体的分裂可能也是促成 有领类双鼻孔起源的一次关键的演化事件, 它允许刺猬基因家族调控鼻基板的发育, 从而 形成侧位的鼻囊. 看甲鱼类是 4.35 3.7 亿年前生活在中国和越南北部的一种地方性色彩很 浓的“甲胄鱼类”。盔甲鱼类曙鱼脑频的三维复原显示其成对的鼻囊位于口鼻腔两侧，而垂 体管向前开向口鼻腔中部，三者彼此分开。因此，盔甲鱼类化石提供了无领类鼻垂体复合 体在领起源之前分裂的关键证据，从而佐证了领演化的异位理论. 藉助于同步辐射 X 射线 断层扫描技术，本文进一步揭示出看甲鱼类可能已经具有了有领类特有的颅桁衍生构造(譬 如眀鼻间隔、䇻骨板), 为探讨脊椎动物脑颅在领的起源之前如何重组提供了关键资料. 在 探讨领的起源及相关问题上，盔甲鱼类较之于骨甲鱼类在很多方面是一个更好的对比模型. 盔甲鱼类脑颅所揭示出的一些与有领类共有的进步性状, 表明盔甲鱼类有可能取代骨甲鱼 类成为有领脊椎动物的姐妹群. 本研究提供了一个发育生物学假说与古生物化石实证相互 交叉的有趣案例.
\end{abstract}

\section{关键词}

领

无领类

有领类

盔甲鱼类

颅桁

演化发育生物学
领的起源是脊椎动物演化史上一次非常关键的 创新, 也许是最具革命性的演化事件, 深刻影响了脊 椎动物的演化方向 ${ }^{[1,2]}$. 领出现的重要意义是显而易 见的, 因为它使脊椎动物成为“顶级掠食者”, 爬上了 整个食物链的最顶端 ${ }^{[3,4]}$. 自此以后, 脊椎动物结束 了简单的滤食生活, 向更为广阔的生态空间拓展, 演 化出了包括我们人类在内的形形色色的有领脊椎动 物，它们占据了今天脊椎动物物种多样性的 $99.8 \%$ 以 上 $^{[5]}$. 但是, 由于缺乏代表领的祖先状态的化石证据, 领的起源过程至今仍谜团重重 ${ }^{[6]}$. 盲鳗类和七鳃鳂类
是现生脊椎动物中仅有的无领类(圆口类)，被认为是 现生有领准椎动物的姐妹群 ${ }^{[7,8]}$. 它们的系统学位置 对我们认识脊椎动物的特征演化极向具有重要作 用 ${ }^{[9]}$. 然而, 由于圆口类主要营寄生生活, 特化现象 严重, 其与现生有领类之间存在着不可逾越的形态 鸿沟 ${ }^{[10]}$. 这导致圆口类在解决领的起源及脊椎动物 头骨和身体结构式样(body plan)重组等关键问题上 并没有提供令人满意的答案 ${ }^{[1]}$.

早已灭绝的戴盔披甲的“甲胄鱼类”，在系统发 育关系上被普遍认为是现生无领类和有领类之间的

英文版见: Gai Z K, Zhu M. The origin of the vertebrate jaw: Intersection between developmental biology-based model and fossil evidence. Chin Sci Bull, 2012, 57, doi: 10.1007/s11434-012-5372-z 


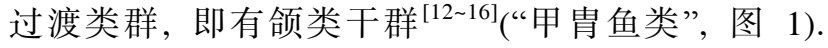
这些类群对我们认识有领类如何逐步获得其特征组 合具有举足轻重的作用 ${ }^{[11]}$. 例如，这些无领的“甲胄 鱼类”表明现生有领类的许多关键特征，像外骨骼、 软骨外成骨、巩膜环、胸鰙和上歪尾等, 实际上早在 领的起源之前就已经出现 ${ }^{[12,17]}$. 但是, 令人遗憾的是, 这些“甲胄鱼类”并没有展示出任何一个构造能够代 表有领脊椎动物领弓 (腭方软骨和麦氏软骨)的祖先 状态 ${ }^{[10]}$. 另外, 由于圆口类和有领类的鳃弓相对于 鳃丝的位置完全不同(前者位于鳃丝的外侧, 后者位 于鳃丝的内侧), 无领类和有领类之间鳃弓是否同源 的问题已激烈争论了上百年 ${ }^{[10,18 ~ 24]}$. 从某种意义上 讲, 领的起源看起来就像是脊椎动物演化上的一次 突发事件, 可能并不存在祖先或过渡状态, 这与有领 类内耳水平半规管的起源有点类似 ${ }^{[25]}$.

除了通过传统的比较解剖学寻找领的祖先状态 外 ${ }^{[10,26]}$, 分子生物学、发育生物学和比较胚胎学也分 别从不同的角度探寻领的起源. 这些新兴学科的一 系列进展促成了领演化异位理论的提出. 这一理论 是由 Kuratani 和他的研究团队根据七鳃鳂和有领类 头部发育遗传学的对比研究提出的, 认为无领类鼻 垂体复合体的分裂是领发育的最根本的先决条件,
应该发生在领的起源之前 ${ }^{[6,27 ~ 32]}$. 另外, 鼻垂体复合 体的分裂也被看作是促成有领类双鼻孔起源的一次 关键事件 ${ }^{[10,12,13]}$. 最近, 我们对盔甲鱼类脑颅比较解 剖学的研究提供了鼻垂体复合体在无领类中分裂的 最早的化石证据, 从而佐证了领演化的异位理论 ${ }^{[11]}$. 盔甲鱼类是 4.35 3.70 亿年前“甲贯鱼类”最为繁盛的 类群之一, 目前已经建立起亚纲一级的分类单元, 但 仅发现于中国和越南北部的志留系和泥盆系 ${ }^{[33]}$. 应 用同步辐射 $\mathrm{X}$ 射线断层扫描, 本文提出了一些颖桁 衍生构造(如眀鼻间隔、篮骨板)在盔甲鱼类中存在的 证据, 这些证据表明盔甲鱼类至少拥有了颖桁的雉 形构造, 从而为领演化的异位理论提供了新的化石 证据 ${ }^{[11]}$. 长期以来, 有领脊椎动物的颅桁构造一直 被认为是有领类超越无领类的一次主要的发育创

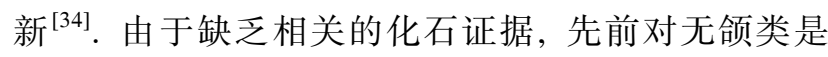
否具有真正的颅桁构造的讨论主要依赖于发育生物 学模型. 颅桁衍生构造在无领类盛甲鱼类中的发现 为我们进一步揭示出脊椎动物头骨在领的起源之前 重组的过程. 在此基础上, 本文还讨论了盔甲鱼脑颖 新生构造对未来重建脊椎动物系统发育关系的潜在 影响. 我们的研究提供了一个发育生物学假说与古 生物化石实证相互交叉的有趣案例.
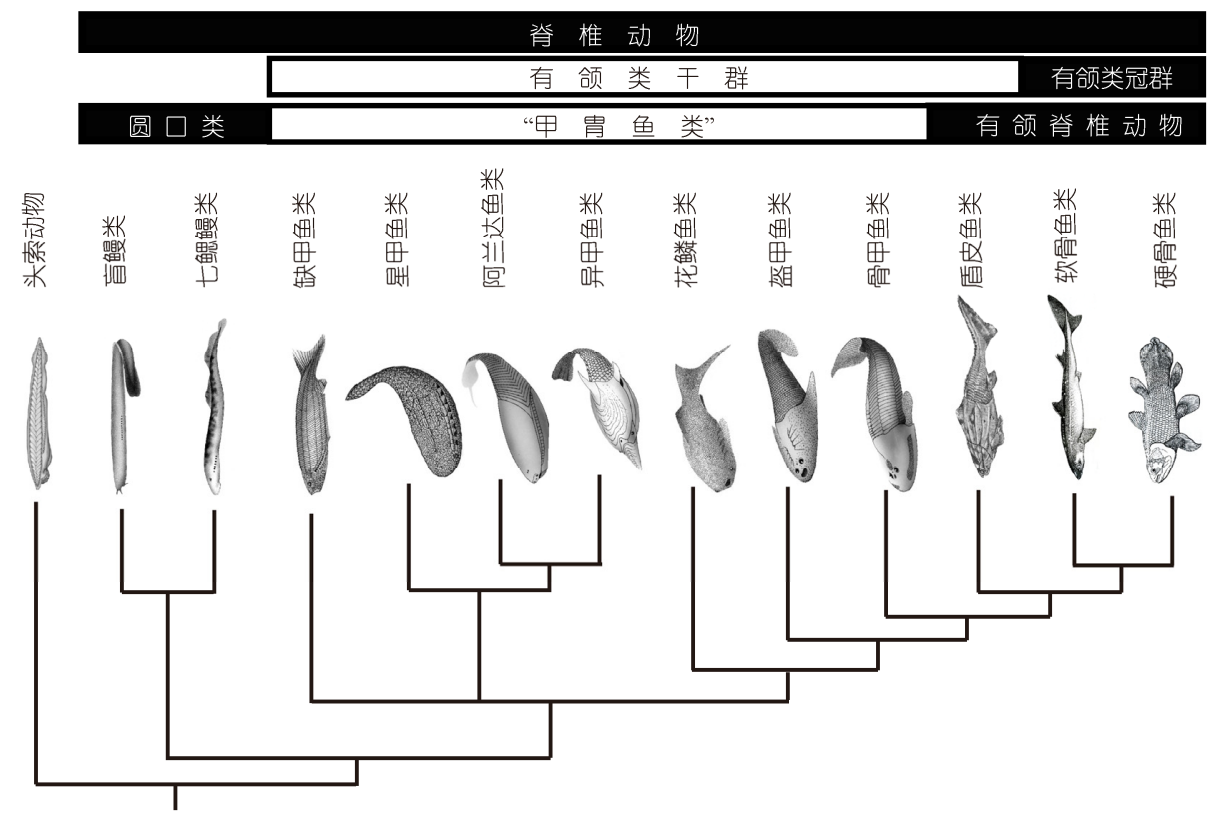

图 1 脊椎动物系统发育框架

圆口类(七鳃鳗和盲鳗)是单系还是并系类群是一个世纪以来热烈争论的话题之一. 由于“甲胄鱼类”比现生的圆口类在系统学位置上离 有领脊椎动物更近，因此它们落人了有领类的全类群. 换言之, “甲胄鱼类”虽然没有领，但它们在分类上属于有领类干群，而真正有领 的脊椎动物只包括盾皮鱼类和有领类冠群, 修改自文献[7,16] 


\section{1 脊椎动物领起源的发育模型：异位理论}

脊椎动物最基本的特征是具有神经脊 (neural crest)与神经基板 (placodes), 它们是脊椎动物脑颖和 咽颖的发育基础(如神经基板发育成成对的感觉器官,

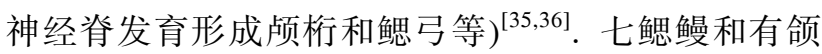
类的比较胚胎学研究表明脊椎动物神经脊细胞的初 始分布在胚胎早期表现出很强的保守性. 在咽肧期 阶段 (pharyngula), 神经脊细胞的分布可以区分出 3 个明显的聚集区, 从前向后分别是三叉神经脊细胞 (trigeminal crest cells)、舌弓神经脊细胞(hyoid crest cells)和鳃弓神经脊细胞 (branchial crest cells) (分别对 应粉红、黄和绿色区域, 图 2(a), (b) ) ${ }^{[27,37]}$. 三叉神经 脊细胞(粉红, 图 2(a), (b)) 主要分布在第一咽囊之前 的区域(PA1, 图 2(a), (b)), 又可进一步划分为领前神 经脊细胞 (premandibular crest cells) (pmc, 图 2(c) (f)) 和领弓神经脊细胞 (mandibular crest cells)(mc, 图 2(c) (f)). 这部分的神经脊细胞是后期分化成脊椎动 物口器及相关构造(如上下领)的基础材料, 对领的发 育有着非常重要的影响 ${ }^{[6,27,37]}$.

脊椎动物咽弓 (包括领弓) 的发育可以看作是上 述神经脊细胞在笛卡尔网格状调控基因网络调控下 的细胞命运决定的结果(图 2(a),(b) $)^{[31]}$. Hox 基因家 族, 又称同源异型盒基因, 是真后生动物中一类主要 的发育调控基因, 主要沿着体轴的前后方向表达. 通 过一种嵌套表达的模式, 每一个咽弓都获得各自位 置的基因信号, 从而向各自特定的形态分化(Hox, 图 2(a),(b)). 在有领类中, 领主要是从第一咽弓分化而 来(PA1, 图 2(b)). 但是, Hox 基因在第一咽弓上却并 没有表达, 被称为有领类领弓 Hox 基因表达缺失 态 ${ }^{[27,38]}$. 相反, Cohn ${ }^{[39]}$ 发现 Hox 基因的 HoxL6 在无领 类七鳃鳗的第一咽弓上却有所表达, 进而建议 Hox 基因在有领类领弓上的缺失表达可能是导致脊椎动 物领起源的一个主要因素. 但是, 这一发现却并没有 在七鳃鳗的另一个种 Lethenteron japonicum 中得到证 实 ${ }^{[38]}$. Kuratani ${ }^{[28]}$ 认为领弓的这种 Hox 基因表达缺失 状态很可能在七鳃鳗和有领类的共同祖先中就建立 起来了, 它对于领的起源仍然具有十分重要的意义, 如在缺少 Hox 基因表达约束的情况下, 三叉神经脊 的外胚层间质细胞很容易改变自己分布范围.

同理，同源异型盒基因家族的 $D l x$ 基因通过体轴 背腹方向的嵌套表达来调控有领类每一个咽弓 (包括
领弓)在身体背腹方向上的发育 $(D l x \text {, 图 2(b) })^{[40]}$. 但 是, $D l x$ 基因家族的这种嵌套表达方式在七鳃撸的胚 胎发育中却没有观察到(Dlx, 图 2(a)). 与 Hox 基因在 领弓上的缺失表达相比, $D l x$ 基因在有领类的领弓上 的嵌套表达可以很清楚观察到 ${ }^{[40]}$. 在像 $D l x$ 和 $M s x$ 等同源异型盒基因(统称口腔发育调控基因)的帮助 下, 三叉神经脊的外胚层间质细胞会直接发育成七 鳃鳗和有领类的口器及相关构造. 根据异位理论 ${ }^{[30]}$, 领的起源可能跟口腔发育调控基因(如 $D l x, M s x$ 和相 关生长因子 FGF, BMP, 图 2(c), (d)) 向后的异位表达 有关. 在七鳃撸的胚胎发育过程中, 口腔发育调控基 因同时在领弓神经脊和领前神经脊外胚层间质细胞 上表达 $(D l x, \mathrm{FGF} 8, \mathrm{BMP} 4$, 图 2(c)). 从而, 领前神经 脊外胚层间质细胞分化成了口的上唇(upper lip)(ulp, 图 2(a), (c)), 而领弓神经脊外胚层间质细胞分化成了 下唇(lower lip)和缘膜(velum) (llp, vel, 图 2(a), (c)). 相比之下, 有领类的口腔发育调控基因的表达仅限 于领弓区 (Dlx, FGF8, BMP4, 图 2(d)). 因此, 只有领 弓神经脊外胚层间质细胞分化成为口器(如上、下 领)(mx, mn, 图 2(b),(d)). 由于口腔发育调控基因向 后的异位表达, 原来用来分化成无领类的上唇的那部 分领前神经脊外胚层间质细胞(ulp, 图 2(a)，(c)，(e)), 在有领类中并未发育成口器的相关构造, 而是分化成 了硕枌(tr, 图 2(d), (f)). 因此, 领的起源, 可能是在上 皮-外胚层间质细胞相互作用中，由于口腔发育调控 基因的异位表达导致的一次演化上的创新 ${ }^{[27]}$.

\section{2 领起源的最根本的先决条件：鼻垂体复 合体的分裂}

根据异位理论 ${ }^{[6,27 ~ 31]}$, 口腔发育调控基因的异位 表达诱导领的发育, 这一过程应该发生在双鼻孔和 颖桁出现之后. 圆口类与有领类头部结构的一个重 要区别是仅具有位于头顶中间位置的单个鼻孔 (no, 图 3(a), (b)), 该鼻孔通过鼻垂体管(hy.d，图 3(a), (b)) 跟鼻垂体复合体相连. 鼻垂体复合体是鼻囊和垂体 紧密相依形成的复合构造, 在发育上来自中央的一 块基板——鼻垂体板 (nasohypophyseal placode)(nhp, 图 2(e)). 相比之下, 有领脊椎动物具有一对彼此分 离的鼻囊(na, 图 3(e)), 并通过一对独立的外鼻孔(no, 图 3(e))通向外界, 垂体管(hy.d, 图 3(e))向下延伸通 向口腔顶部. 因此, 有领类的鼻囊与垂体彼此独立, 不再形成鼻垂体复合体, 从发育上看, 这三者是来自 

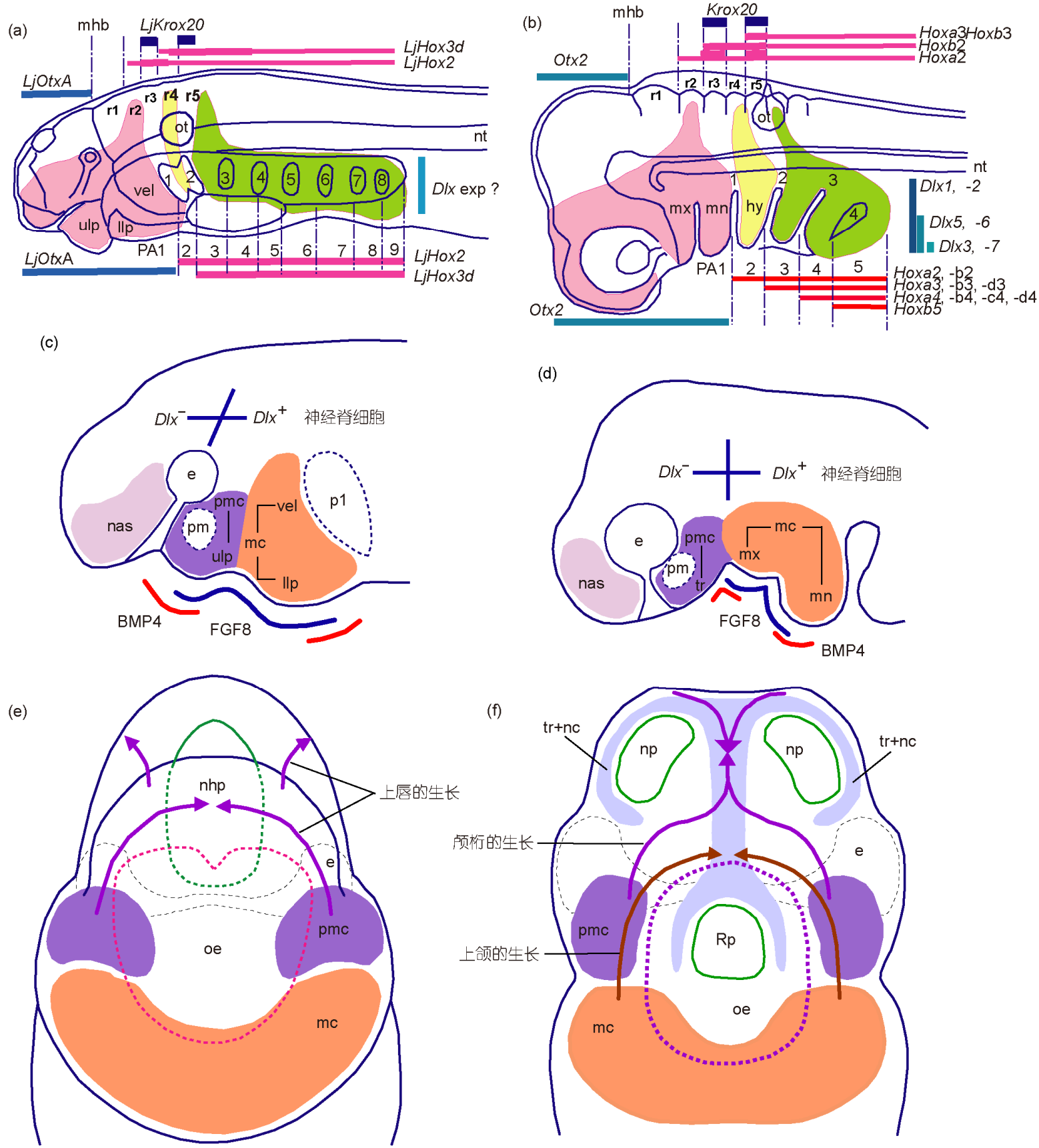

图 2 七鰓鳗和有领脊椎动物胚胎发育的比较

七鳃鳗 (a)和有领脊椎动物 (b)神经脊细胞的初始分布和调控基因的表达模式, 粉色、黄色和绿色分别代表了三叉、舌弓和鳃弓神经脊细 胞聚集区, 引自 Kuratani[27, 图 3A]. 七鳃鳗(c)和有领脊椎动物(d)三叉神经脊细胞的分布和口腔发育调控基因的表达模式, 示口腔发 育调控基因 $D l x 、 M s x$ 和它们的生长因子 FGF8、BMP4 在有领类中有一个向后的异位表达, 引自 Shigetani 等人 [30, 图 3A D]. 七鳃 鳗(e)和有领脊椎动物(f)口腔外胚层、鼻垂体复合体和三叉神经脊细胞生长的拓扑关系, 引自 Kuratani[27, 图 $5 \mathrm{C}]$ 和 $\mathrm{Kuratani}$ 等人 [6, 图 9a]. 在有领脊椎动物中, 领前神经脊细胞向前方鼻基板和拉特克囊之间的空间生长, 形成㐿桁, 领弓神经脊细胞向拉特克囊的前侧 方生长形成上领(f). 在七鳃鳗中, 领前神经脊细胞的向前生长因受到前方中央鼻垂体基板的阻挡，只能沿着其腹面生长，发育成上唇 (e). BMP, 骨形成因子; e, 眼; FGF, 成纤维细胞生长因子; hy, 舌弓; llp, 下唇; mc, 领弓神经脊细胞; mhb, 中脑-后脑界限; mn, 下领突; $\mathrm{mx}$, 上领突; nas, 鼻区; nc, 鼻囊; nhp, 鼻垂体基板; np, 鼻基板; nt, 脊索; oe, 口腔外胚层; ot, 听囊; PA, 咽弓; pm, 领前中胚层; pmc 领前神经脊细胞; $\mathrm{r}_{1} \sim \mathrm{r}_{5}$, 菱脑原节; $\mathrm{Rp}$, 拉特克囊; $\mathrm{tr}$, 㐿桁; $\mathrm{ulp}$, 上唇; vel, 缘膜; $1 \sim 8$, 咽裂或咽囊 


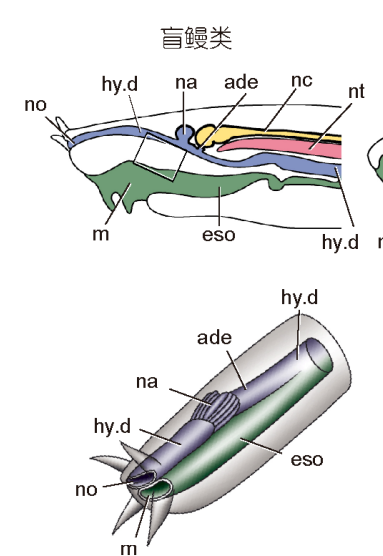

(a)
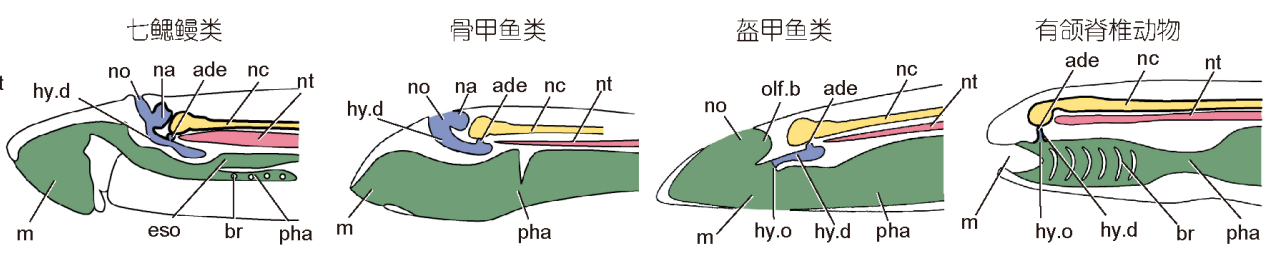

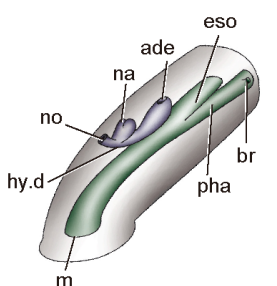

(b)

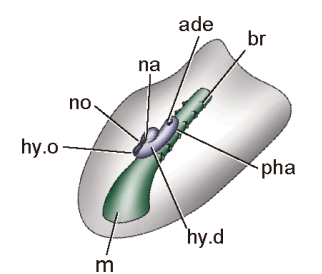

(c)

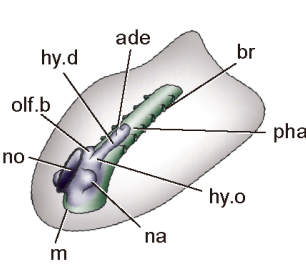

(d)

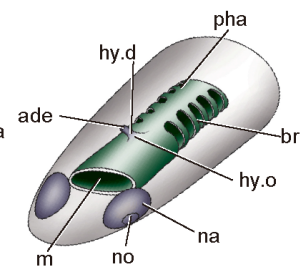

(e)

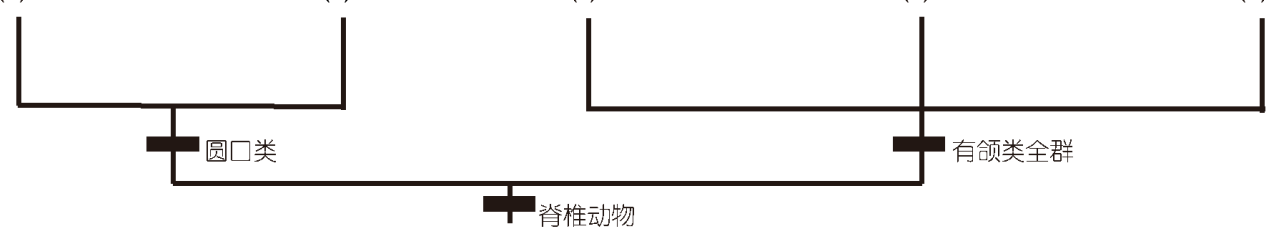

图 3 鼻垂体复合体的早期演化

在探讨领的起源及相关问题上，盔甲鱼类在很多方面是一个更好的对比模型，这大大增加了盔甲鱼类取代骨甲鱼类成为有领类姐妹群 的潜在可能性，修改自文献[11]. ade，脑下垂体；br，鳃囊或鳃裂; eso, 食道; hy.d, 垂体管; hy.o, 垂体孔; m, 口; nc, 神经索; na，鼻囊; no, 鼻孔; nt, 脊索; olf.b, 嗅球; pha, 咽; 下同

3 块相互独立的基板, 即一对侧位的鼻基板 (nasal placodes)(np, 图 2(f)) 和后面中间位置的拉特克囊 (Rathke's pouch)(Rp, 图 2(f)). 在有领脊椎动物胚胎 发育中, 鼻基板和拉特克囊的这种拓扑关系为领前 神经脊细胞 (pmc, 图 2(f)) 向前生长形成颅桁, 领弓神 经脊细胞 $(\mathrm{mc}$, 图 2(f)) 向前侧方生长形成上下领 $(\mathrm{mx}$, $\mathrm{mn}$, 图 2(b), (d)) 提供了可能. 相比之下, 在七鳃鳗胚 胎发育中, 领前神经脊细胞 (pmc, 图 2(e)) 的向前生 长因受到中央鼻垂体板的阻挡, 而只能沿着其腹面 生长形成上唇(ulp, 图 2(a), (c)). 因此, 领的发育首 先要求鼻垂体复合体的分裂为乑桁的发育提供空间. Kuratani ${ }^{[27]}$ 预测在化石记录中有领类的无领祖先中 可能会发现一些具有双鼻孔和颅桁的类群.

\section{3 鼻垂体复合体分裂与刺猬基因家族的关系}

在无领类向有领类的过渡中, 鼻垂体复合体的 分裂也被看作促成有领类双鼻孔(成对的鼻囊具有独 立的外鼻孔)起源的一个主要事件 ${ }^{[10,12,13]}$. 近年来, 演化发育生物学的一些进展逐渐从分子层面上揭示 出该事件对双鼻孔起源的潜在影响. 刺猬基因家族 (Hedgehog gene family)在调控脊椎动物胚胎模式发 生和器官形成的各个方面都起着非常关键的作用 ${ }^{[41]}$,
其中一个显著的功能就是沿着整个神经管的腹侧中 线来决定胚胎细胞的命运和相关基因的表达模式 ${ }^{[42]}$. 在敲除了刺猬基因家族中的音速刺猬基因 (Sonic hedgehog gene)的小鼠胚胎中 $\left(S h h^{-1}\right)$, 通常侧位成对 的器官如端脑、上下领、视囊、鼻基板等会发生愈合 现象, 在身体中线上形成不成对的结构 ${ }^{[42,43]}$. 这种现 象被统称为前脑无裂畸形, 通常伴随着独眼、愈合的 鼻腔和愈合的端脑室等其他前脑和面部中线上的畸 形缺陷 ${ }^{[42,43]}$. 有趣的是, 在敲除音速刺猬基因 $\left(S h h^{-1}\right)$ 的小鼠胚胎中, 成对鼻囊愈合形成的单鼻腔 ${ }^{[43]}$, 使 我们联想起无领类中的单鼻孔. 最近, 以前未见报道 的刺猬基因家族在七鳃鳗鼻垂体板上的表达被明确 观察到了 ${ }^{[44]}(S h h$, 图 4). 这很可能表明分离成对鼻囊 的分子机制在七鳃鳗和有领类的共同祖先中就已建 立起来(图 4). 在圆口类中, 嗅觉器官从单个的基板 ——鼻垂体板发育而来，但是它的原基总是存在一 个中隔膜 ${ }^{[45 ~ 47]}$ 把嗅觉器官分隔成左右两半 ${ }^{[48]}$. 中隔 膜在盲鳗的成体中消失, 但是在七鳃鳗的成体中保 留了下来 ${ }^{[13,49]}$. 所以从某种程度上说, 圆口类的嗅觉 器官可以看作是成对的, 但是彼此离得很近. 另外, 所有脊椎动物都具有成对的嗅神经和嗅球, 也表明 成对的嗅觉器官可能代表了脊椎动物的原始状态 ${ }^{[49]}$. 

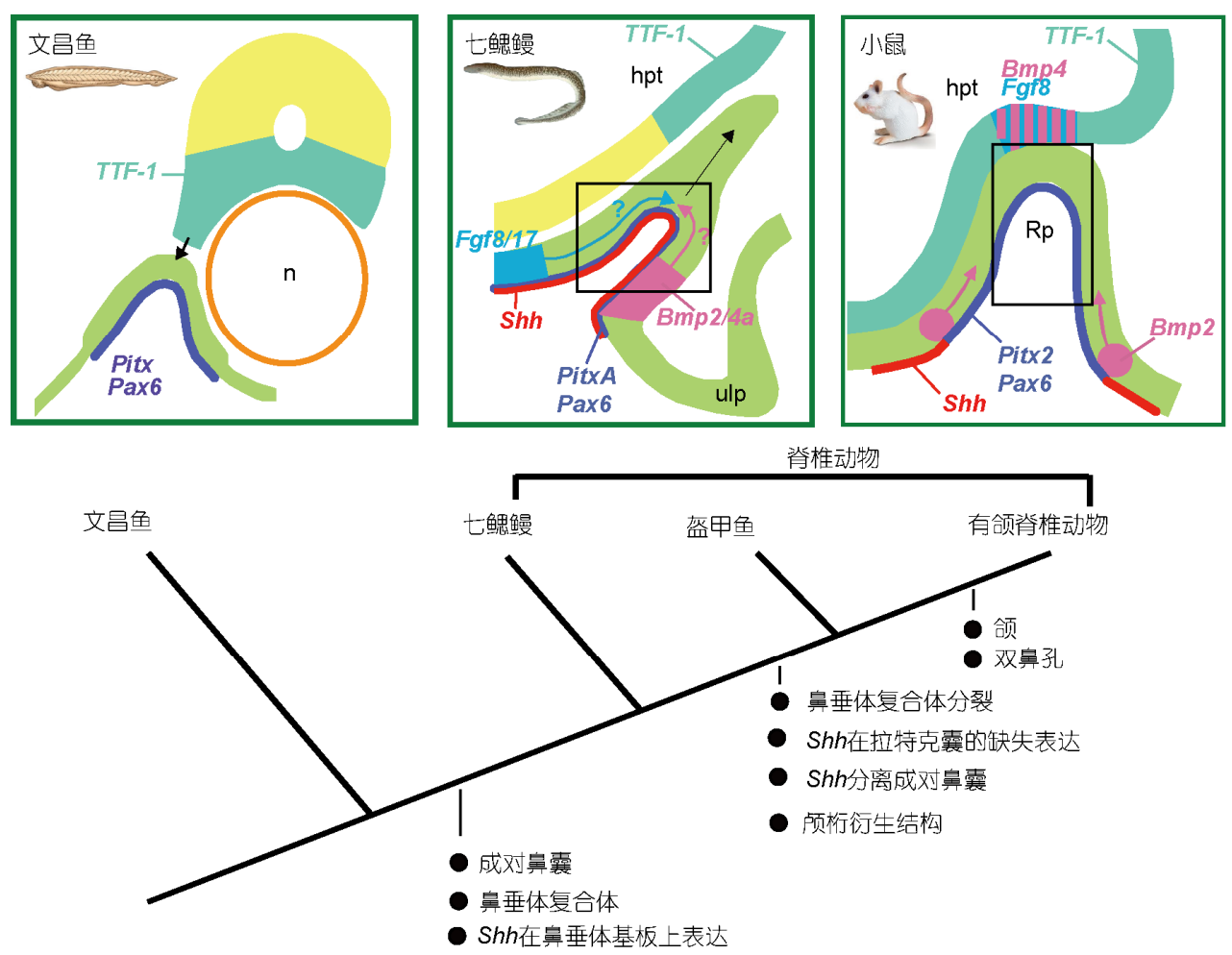

图 4 无领类鼻垂体复合体的分裂与领、双鼻孔、垂体演化的关系

以前未见报道的刺猬基因家族在七鳃鳗鼻垂体基板上的表达最近被明确观察到了 ${ }^{[44]}$, 这很可能表明分离成对鼻囊的分子机制在七鰓撸 和有领类的共同祖先中就已经建立起来了，但是在圆口类中，它们的分离却受到了鼻垂体复合体的限制，而无法分开. 无领类鼻垂体 复合体的分裂可能是影响有领脊椎动物领和双鼻孔起源的一次关键的演化创新, 修改自 Uchida 等人[32，图 8]

这种成对的嗅觉器官很可能远在寒武纪脊椎动物干 群昆明鱼目的海口鱼中就建立起来了 ${ }^{[50 \sim 52]}$. 如果双 鼻孔发育的几个关键因素早在所有脊椎动物的共同 祖先中就建立起来了, 那么这里就很有必要讨论一下 为什么无领类仍然只发育了一个位于中央的单鼻孔.

在脊椎动物中, 嗅觉器官的历史跟垂体的历史 是紧密结合在一起的 ${ }^{[12]}$. 七鳃鳗的嗅觉器官(成对鼻 囊)和垂体发育自一块中央的基板一一鼻垂体板. 虽 然刺猬基因家族在整个鼻垂体板上有所表达 ${ }^{[44]}$, 但 是鼻基板的分离很能受到整个鼻垂体复合体的限制, 而无法诱导鼻囊在脑㐿侧位的发育. 因此, 一对愈合 的鼻囊发育在了头部中央, 并通过单个鼻孔开口于 外界. 与七鳃鳗一样，在有领类胚胎发育早期，鼻基 板和垂体基板(拉特克囊)也是彼此距离很近 ${ }^{[53]}$, 但是 它们在拓扑学上是彼此独立的, 不再发育为鼻垂体 复合体. 像前面讨论的一样, 鼻垂体复合体分裂所产 生的这种拓扑关系为神经膌外胚层间质细胞 ${ }^{[6,27]}$ 和
口腔外胚层细胞的重新组织提供了先决条件 ${ }^{[32]}$, 因 此可以看作是领起源和垂体演化的一次关键创新. 在有领类发育中，刺猬基因家族中的音速刺猬基因 在整个间脑腹面、口腔外胚层(包括拉特克囊)以及鼻 基板上都有所表达，但是随后在拉特克囊上的表达 缺失，在口腔上皮上产生了一个音速刺猬基因的表 达界限 ${ }^{[32,43,54]}$ (图 4). 在随后的发育阶段, 成对的鼻 基板和拉特克囊便彼此迅速分离. Kawamura 等人 ${ }^{[55]}$ 以及 Gleiberman 等人 ${ }^{[56]}$ 认为它们这种快速的分离可 能在某种程度上是由于这部分大脑向吻端的生长, 垂直诱导了拉特克囊．考虑到在敲除音速刺猬基因 的小鼠胚胎中, 成对的鼻囊不再分离, 而是愈合形成 单鼻腔 ${ }^{[33]}$, 我们怀疑这种快速的分离很可能与刺猬 基因家族调控鼻囊侧位的发育有一定的关系. 如此, 鼻垂体复合体的分裂可能也是双鼻孔起源前的一次 主要事件，它允许刺猬基因家族调控鼻基板的发育, 从而形成侧位的鼻囊. 


\section{4 与化石实证的交叉：盔甲鱼类脑颖的演 化创新}

虽然无领类仅有盲鳗和七鳃鳗子遗到现在, 但 在志留、泥盆纪时期却非常繁盛, 主要是一些戴盔披 甲的“甲胄鱼类”，包括阿兰达鱼类、星甲鱼类、异甲 鱼类、缺甲鱼类、盔甲鱼类、茄甲鱼类、骨甲鱼类和 花鳞鱼类等几个主要类群(图 1) ${ }^{[12,57]}$. 目前, 这些类 群在系统发育关系上被一致认为是现生圆口类和有 领类之间的过渡类群，即有领类干群(图 1) ${ }^{[12 \sim 15,58 \sim 61]}$, 因此对我们了解脊椎动物的早期演化, 特别是有领 类如何逐步获得其特征组合, 起着至关重要的作用. 在这些类群当中, 生存于大约 4.2 3.7 亿年前的骨甲 鱼类一直被认为是与有领类系统发育关系最近的无 领类(图 1), 因为它们与有领类有很多共近裔性状, 如肩带支撑的成对胸鳍、有骨细胞的软骨外成骨、巩 膜环以及上歪尾等 ${ }^{[12,13]}$. 但是, 20 世纪 20 年代通过 连续磨片法对骨甲鱼类脑硕的三维复原显示: 骨甲 鱼类的鼻垂体系统与七鳃鳗的极其相似, 只有一个 位于头顶中央的鼻垂体复合器官(图 3), 也就是说骨 甲鱼类在解决领的起源这一关键问题上, 并未提供 有力的证据.

除了骨甲鱼类，大约同时代的盔甲鱼类是惟一 一个具有软骨脑㐿三维矿化保存的“甲胄鱼类”, ${ }^{211,62]}$. 目前, 盔甲鱼类被认为是骨甲鱼类和有领类的姐妹 群, 是可能解开有领类起源之谜的另一个关键类群 (图 1). 应用同步辐射 $X$ 射线断层扫描和计算机三维 虚拟复原技术, 我们已经详细阐明了盛甲鱼类曙鱼 脑颅的总体解剖特征, 并提供了脊椎动物演化史上 无领类鼻垂体复合体分裂的最早的化石证 ${ }^{[1]}$. 我们 的研究结果显示盛甲鱼类的成对鼻囊 (na, 图 5(b) (e)) 位于口鼻腔(on.c, 图 5(c))两侧, 而垂体管(hy.d, 图 5(a) (c), (e)) 向前开向口鼻腔中部, 三者完全分开. 这一结果跟圆口类和骨甲鱼类头顶中央的鼻垂体复 合体完全不同, 而跟有领类非常的相似. 因此, 盔甲 鱼类很可能已经具备了目前发育模型所认为的领发 育所必需的先决条件之一. 这里, 我们进一步报道盔 甲鱼类可能已经具有了有领类特有的颖桁衍生构造 (譬如眶鼻间隔、篮骨板), 为探讨脊椎动物脑颅在领 的起源之前如何重组提供了新资料.

盔甲鱼类最典型的特征是在头甲前部中央有一 个很大的中背孔(no, 图 5(c) (e)), 既充当鼻孔, 也是
主要的进水孔. 曙鱼的中背孔呈纵长椭圆形, 由两侧 软骨的匙状长吻(rostrum) (ro, 图 5(d), (e))包围而成. 在中背孔下面是一个很大的口鼻腔 (oronasal cavity)(on.c, 图 5(c)), 口鼻腔向上、向下、向后分别跟鼻 孔(no, 图 5(c) (e))、口(m, 图 3(d)) 和咽腔(pha, 图 $3(\mathrm{~d})$ )相通. 一对很大的鼻囊(na，图 5(c) (e))呈圆锥 状, 位于口鼻腔的两侧. 由于盔甲鱼类的鼻囊已经像 有领类那样位于眶孔(orb, 图 5(c) (e)) 的前侧方, 因 此在鼻囊和眶孔之间存在一对狭长的软骨薄片 眶鼻间隔(orbitonasal lamina)(on.l, 图 5(c), (d)), 形成 鼻腔的侧后壁和眀腔的前壁. 跟有领类的眀鼻间隔 一样, 盔甲鱼类的眀鼻间隔被特征性的神经和血管 洞穿, 如三叉神经浅眼支 $\left(\mathrm{V}_{0}\right.$, 图 5(c) (e))、深眼支 $\left(\mathrm{V}_{1}\right.$, 图 5(c) (e))、眶鼻动脉 (on.a, 图 5(c) (e)) 和眶鼻静脉 (on.v，图 5(c) (e))等. 眶鼻间隔呈“W”状，中央向前 凸出一短的软骨突 (et.r, 图 5(a), (b), (e)), 可能相当 于有领类的篮骨板(ethmoid plate), 支撑并分隔成对 的嗅球(olfactory bulbs) (olf.b, 图 5(a) (c), (e)). 与有 领类相比, 盔甲鱼类的篮骨板相对较小, 只能称为篮 骨突(ethmoid process), 它并未向前充分延伸, 把两 侧的鼻囊完全分开(鼻间隔尚未形成). 因此, 盔甲鱼 两侧的鼻囊仍然共用一个鼻孔一一背孔. 匙状长 吻、眶鼻间隔、篮骨突都被认为是有领脊椎动物颖桁 的主要衍生构造. 在曙鱼的脑㐿中识别出颖桁的衍 生构造, 表明盔甲鱼类至少拥有了有领脊椎动物颖 桁的雉形. 颖桁长期以来一直被认为是有领类超越 无领类的一次主要的演化创新 ${ }^{[34]}$. 虽然“颖桁”在圆 口类中也有所报道 ${ }^{[63,64]}$, 但是七鳃鳗的“硕桁”包裹 着垂体, 并向前延伸包裹鼻囊. 它位于脊索的两侧, 而非前端 ${ }^{[65]}$, 因此更可能代表了侧索软骨的向前延 伸 ${ }^{[64,66]}$. 胚胎发育的证据也表明七鳃鳗的所谓“频 桁”是从领弓中胚层发育而来, 可能与有领类外胚层 间质来源的颖桁并没有同源关系 ${ }^{[27]}$. 虽然我们无法 获知化石无领类的发育过程, 但可以通过硕桁的衍 生构造来判断㐿桁在化石无领类中是否存在. 骨甲 鱼类的鼻垂体复合体和眶孔之间也是由软骨分隔, 但是这个软骨薄片位于眀孔内侧, 而且远在领弓, 甚 至舌弓的后面 ${ }^{[12,13]}$. 在有领类中, 颅桁的衍生构造都 位于领弓的前面, 因为它们发育上来自都发育自领 前神经凎 ${ }^{[6,27]}$. 因此, 在骨甲鱼类中, 包裹鼻垂体复 合体的软骨很可能与七鳃鳗一样属于侧索软骨的向 前延伸. 由于其他的“甲胄鱼类”中尚没有钙化或矿 

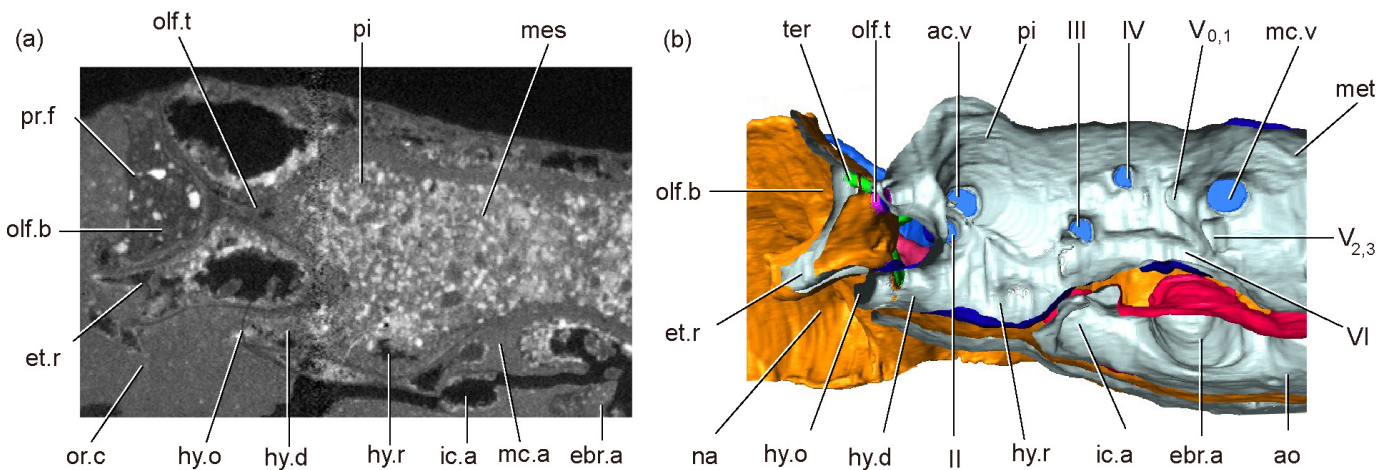

(c)

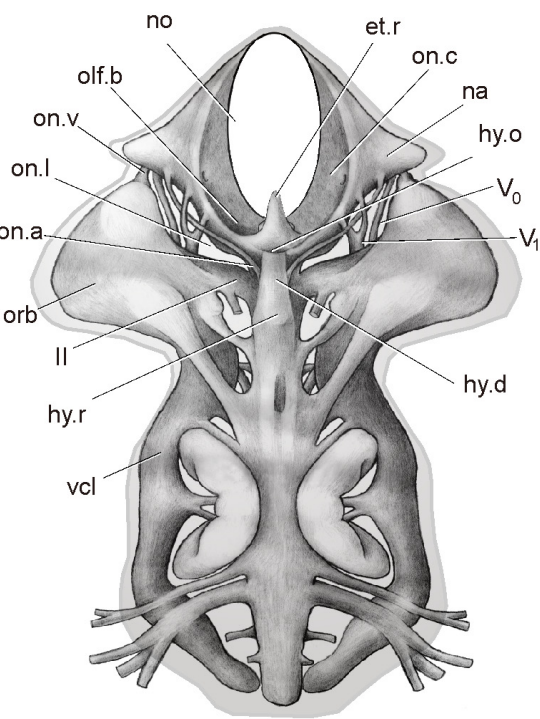

(d)

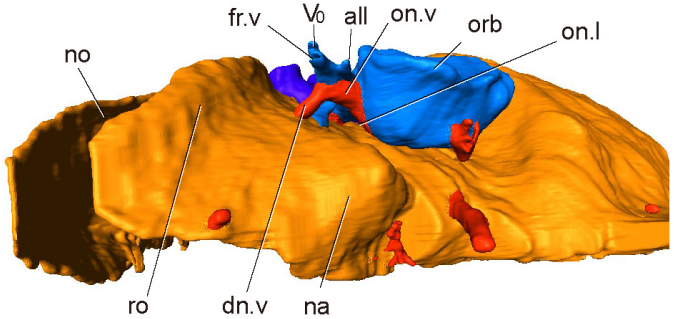

(e)

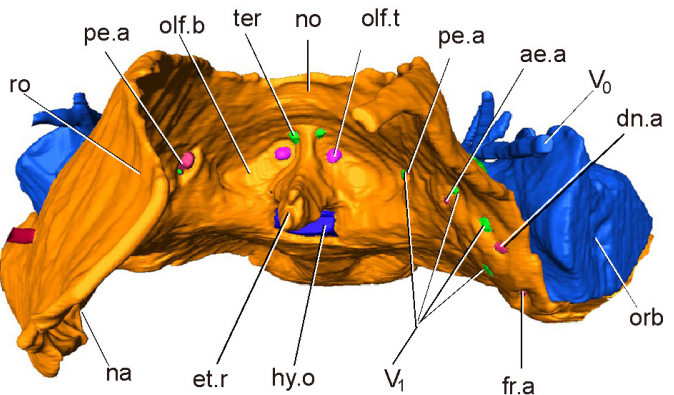

图 5 浙江曙鱼(来自中国浙江 4.3 亿年前的一种无领的鱼类)的脑颖解剖

(a) (e) 示频桁的衍生构造(匙状长吻、眶鼻间隔、篮骨突)和相关特征性的神经(三叉神经浅眼支、深眼支)和血管(眶鼻动脉、眶鼻静脉). (a) 同 步辐射 X 光断层扫描数据的中矢切片(512/1024), 标本 V14334.3. (b) 脑颖内模三维虚拟复原的中矢切面(V14334.3), 示鼻囊和垂体管的拓扑关 系. (c) 脑颖内膜的复原, 腹视. (d) 头骨内模的三维虚拟复原, 前侧视, 重建自标本 V14334.1. (e) 脑颖篮区的三维虚拟复原, 前视, 重建自标 本 V14334.3. ac.v, 大脑前静脉; ae.a, 笁前动脉; all, 前侧线神经; ao, 背大动脉; dn.a, 鼻背动脉; dn.v, 鼻背静脉; ebr.a, 出鰓动脉; et.r, 篮骨突; fr.a, 额动脉; fr.v, 额静脉; hy.r, 垂体凹; ic.a, 颈内动脉; mc.v, 大脑中静脉; mc.a, 大脑中动脉; mes, 中脑; met 后脑; olf.t, 嗅束; on.a, 眶鼻动脉; on.c, 口 鼻腔; on.1, 眶鼻间隔; on.v, 眶鼻静脉; orb, 眶孔; or.c，口腔; pe.a, 篎后动脉; pi，松果器; pr.f，脑前窗; ro, 匙状吻; ter, 端神经; vcl, 头侧静脉或 颈背静脉; II, III, IV, $\mathrm{V}_{0}, \mathrm{~V}_{1}, \mathrm{~V}_{0,1}, \mathrm{~V}_{2,3}, \mathrm{VI}$ 分别为视神经 (II), 动眼神经 (III), 滑车神经 (IV), 三叉神经浅眼支 $\left(\mathrm{V}_{0}\right)$, 深眼支 $\left(\mathrm{V}_{1}\right)$, 眼支 ( $\left.\mathrm{V}_{0,1}\right)$, 领支 $\left(\mathrm{V}_{2,3}\right)$, 和外展神经 $(\mathrm{VI})$

化的软骨内颖保存，这些类群是否拥有真正的颅桁 尚不清楚. 所以，盔甲鱼类可能提供了颖桁在无领鱼 类中最早出现的化石证据.

我们的结果显示：在探讨领的起源及相关问题 上, 盔甲鱼类较之于骨甲鱼类在很多方面是一个更 好的对比模型．除了具有眶鼻间隔、笁骨突等颅桁衍 生构造外, 盔甲鱼类还与有领脊椎动物共有其他一 些近裔性状, 如与大脑半球分离的嗅球、独立的嗅
束、端神经、成对侧位的鼻囊、鼻垂体分离、垂体管 开向口腔等 ${ }^{[11,62]}$. 这大大增加了盔甲鱼类取代骨甲 鱼类而成为有领脊椎动物姐妹群的可能性(图 3).

\section{5 结论}

（1）部分频桁衍生构造(如眶鼻间隔、篮骨突)在 盔甲鱼类中的发现，表明有领类特有的颖桁可能在 领的起源之前就已经出现, 这为我们探讨脊椎动物 
的头骨在领的起源之前如何重组提供了关键的资料.

(2) 成对的鼻囊和分离鼻囊的分子机制可能在 七鳃鳗和有领类的共同祖先中就已经建立起来了, 但是它们的相互分离在圆口类中很可能受到了鼻垂 体复合体的限制. 因此, 鼻垂体复合体的分裂可能也 是促成有领类双鼻孔起源的一次非常关键的创新, 它允许刺猬基因家族调控鼻基板的发育，从而形成 侧位的鼻囊.

(3) 鼻垂体复合体的分裂是脊椎动物领起源前 发生的一次非常关键的事件, 它为领的起源提供了 最基本的先决条件. 盔甲鱼类提供了目前脊椎动物 谱系上鼻囊从垂体分离的最早的化石证据. 盛甲鱼 类反映了脊椎动物领起源前的一个中间状态, 即阻 碍外胚层间质细胞向前生长的障碍已经不复存在. 盔甲鱼类的化石证据表明这次事件至少发生在 4.35
亿年前.

（4）没有化石证据表明脊椎动物的双鼻孔在领 起源之前已经出现，但是一种中间状态，即位于脑颅 侧位的成对鼻囊和独立的垂体器官出现在了无领的 盔甲鱼类. 双鼻孔和领可能在通向已灭绝的盾皮类 和有领类冠群的支系上才真正出现.

(5) 在探讨领的起源及相关问题上，盔甲鱼类在 很多方面是一个更好的对比模型. 这表明盔甲鱼类 有可能取代骨甲鱼类, 而成为有领脊椎动物的姐妹 群.

（6）通常认为有领脊椎动物的起源跟无领类采 取越来越主动捕食策略有关系 ${ }^{[35,36]}$. 在这一假说没 有得到更多证据的情况下, 盔甲鱼类提供了现生有 领脊椎动物的特征组合是在领的起源之前逐步获得 (非爆发式)的新证据.

\section{参考文献}

1 Maisey J G. Discovering Fossil Fishes. New York: Henry Holt and Company, 1996. 1-223

2 Kimmel C B, Miller C T, Keynes R J. Neural crest patterning and the evolution of the jaw. J Anat, 2001, 199: 105-119

3 Manzanares M, Nieto M A. A celebration of the new head and an evaluation of the new mouth. Neuron, 2003, 37: 895-898

4 Mallatt J. The origin of the vertebrate jaw: Neoclassical ideas versus newer, development-based ideas. Zool Sci, 2008, 25: 990-998

5 Nelson J S. Fishes of the World. 4th ed. New York: Wiley, 2006. 1-624

6 Kuratani S, Nobusada Y, Horigome N, et al. Embryology of the lamprey and evolution of the vertebrate jaw: Insights from molecular and developmental perspectives. Phil Trans R Soc B, 2001, 356: 1615-1632

7 Heimberg A M, Cowper-Sallari R, Sémon M, et al. MicroRNAs reveal the interrelationships of hagfish, lampreys, and gnathostomes and the nature of the ancestral vertebrate. Proc Natl Acad Sci USA, 2010, 107: 19379-19383

8 Janvier P. MicroRNAs revive old views about jawless vertebrate divergence and evolution. Proc Natl Acad Sci USA, 2010, 107: $19137-19138$

9 Kuratani S, Kuraku S, Murakami Y. Lamprey as an evo-devo model: Lessons from comparative embryology and molecular phylogenetics. Genesis, 2002, 34: 175-183

10 Janvier P. Homologies and evolutionary transitions in early vertebrate history. In: Anderson J S, Sues H D, eds. Major Transitions in Vertebrate Evolution. Bloomington and Indianapolis: Indiana University Press, 2007. 57-121

11 Gai Z K, Donoghue P C J, Zhu M, et al. Fossil jawless fish from China foreshadows early jawed vertebrate anatomy. Nature, 2011, 476: 324-327

12 Janvier P. Ostracoderms and the shaping of the gnathostome characters. In: Ahlberg P, ed. Major Events in Early Vertebrate Evolution: Palaeontology, Phylogeny, Genetics and Development. London: Taylor Francis, 2001. 172-186

13 Janvier P. Early Vertebrates. Oxford: Clarendon Press, 1996. 1-393

14 Forey P L. Agnathans recent and fossil, and the origin of jawed vertebrates. Rev Fish Biol Fish, 1995, 5: 267-303

15 Donoghue P C J, Forey P L, Aldridge R J. Conodont affinity and chordate phylogeny. Biol Rev, 2000, 75: 191-251

16 Donoghue P C J, Sansom I J, Downs J P. Early evolution of vertebrate skeletal tissues and cellular interactions, and the canalization of skeletal development. J Exp Zool B Mol Dev Evol, 2006, 306B: 278-294 
17 Long J A, Brian K H, McNamara K J, et al. The phylogenetic origin of jaws in vertebrates: Developmental plasticity and heterochrony. Kirtlandia, 2010, 57: 46-52

18 Goette A. Über die Kiemen der Fische. Z Wiss Zool, 1901, 69: 533-577

19 Schaeffer B, Thomson K S. Reflections on agnathan-gnathostome relationships. In: Jacobs L L, ed. Aspects of Vertebrate History: Essays in Honor of Edwin Harris Colbert. Flagstaff: Museum of Northern Arizona Press, 1980. 19-33

20 Jarvik E. Basic Structure and Evolution of Vertebrates, Volume 1. London: Academic Press, 1980. 1-575

21 Jarvik E. Basic Structure and Evolution of Vertebrates, Volume 2. London: Academic Press, 1980. 1-337

22 Mallatt J. Early vertebrate evolution: Pharyngeal structure and the origin of gnathostomes. J Zool, 1984, 204: 169-183

23 Janvier P. Patterns of diversity in the skull of jawless fishes. In: Hanken J, Hall B K, eds. The Skull. Chicago: University of Chicago Press, 1993. 131-188

24 Janvier P. The phylogeny of the Craniata, with particular reference to the significance of fossil "agnathans". J Vertebr Paleontol, 1981, 1: $121-159$

25 Mazan S, Jaillard D, Baratte B, et al. Otxl gene-controlled morphogenesis of the horizontal semicircular canal and the origin of the gnathostome characteristics. Evol Dev, 2000, 2: 186-193

26 Gegenbaur C. Untersuchungen zur Vergleichenden Anatomie der Wirbeltiere. 3: Das Kopfskelett der Selachier. Leipzig: Englemann, 1872

27 Kuratani S. Evolution of the vertebrate jaw: Comparative embryology and molecular developmental biology reveal the factors behind evolutionary novelty. J Anat, 2004, 205: 335-347

28 Kuratani S. Evolution of the vertebrate jaw: Homology and developmental constraints. Paleontol Res, 2003, 7: 89-102

29 Kuratani S, Murakami Y, Nobusada Y, et al. Developmental fate of the mandibular mesoderm in the lamprey, Lethenteron japonicum: Comparative morphology and development of the gnathostome jaw with special reference to the nature of the trabecula cranii. J Exp Zool B Mol Dev Evol, 2004, 302B: 458-468

30 Shigetani Y, Sugahara F, Kawakami Y, et al. Heterotopic shift of epithelial-mesenchymal interactions in vertebrate jaw evolution. Science, 2002, 296: 1316-1319

31 Shigetani Y, Sugahara F, Kuratani S. A new evolutionary scenario for the vertebrate jaw. BioEssays, 2005, 27: 331-338

32 Uchida K, Murakami Y, Kuraku S, et al. Development of the adenohypophysis in the lamprey: Evolution of epigenetic patterning programs in organogenesis. J Exp Zool B Mol Dev Evol, 2003, 300B: 32-47

33 Zhu M, Gai Z K. Phylogenetic relationships of galeaspids (Agnatha). Front Biol China, 2007, 2: 151-169

34 Maisey J G. Heads and tails: A chordate phylogeny. Cladistics, 1986, 2: 201-256

35 Gans C, Northcutt R G. Neural crest and the origin of the vertebrates: A new head. Science, 1983, 220: 268-274

36 Baker C V H, Schlosser G. Editorial: The evolutionary origin of neural crest and placodes. J Exp Zool B Mol Dev Evol, 2005, 304B: $269-273$

37 Kuratani S. Cephalic neural crest cells and the evolution of craniofacial structures in vertebrates: Morphological and embryological significance of the premandibular-mandibular boundary. Zoology, 2005, 108: 13-25

38 Takio Y, Pasqualetti M, Kuraku S, et al. Lamprey Hox genes and the evolution of jaws. Nature, 2004, 429, doi:10.1038/nature02616

39 Cohn M J. Lamprey Hox genes and the origin of jaws. Nature, 2002, 416: 386-387

40 Depew M J, Lufkin T, Rubenstein J L R. Specification of jaw subdivisions by Dlx genes. Science, 2002, 298: 381-385

41 Varjosalo M, Taipale J. Hedgehog: Functions and mechanisms. Genes Dev, 2008, 22: 2454-2472

42 Chiang C, Ying L, Lee E, et al. Cyclopia and defective axial patterning in mice lacking Sonic hedgehog gene function. Nature, 1996, 383: $407-413$

43 Cooper M K. Teratogen-mediated inhibition of target tissue response to Shh signaling. Science, 1998, 280: 1603-1607

44 Kano S, Xiao J H, Osório J, et al. Two lamprey hedgehog genes share non-coding regulatory sequences and expression patterns with gnathostome hedgehogs. PLoS One, 2010, 5: e13332

45 von Kupffer C. Studien zur Vergleichenden Entwicklungsgeschichte des Kopfes der Kranioten. Heft 4: Zur Kopfentwicklung von Bdellostoma. München und Leipzig: Verlag von J. F. Lehmann, 1900. 1-86

46 Stensiö E A. The cyclostomes with special reference to the diphyletic origin of the Petromyzontida and Myxinoidea. In: Ørvig T, ed. Current Problems of Lower Vertebrate Phylogeney. Nobel Symposium 4, Stockholm: Almqvist \& Wiksell, 1968. 13-70

47 Goodrich E S. Studies on the Structure and Development of Vertebrates. London: Macmillan, 1930

48 Jefferies R P S. The Ancestry of the Vertebrates. London: British Museum (Natural History), 1986

49 Northcutt R G. The brain and sense organs of the earliest vertebrates: Reconstruction of a morphotype. In: Foreman R, Gorbman A, Dodd J, et al, eds. Evolutionary Biology of Primitive Fishes. New York: Plenum Press, 1985. 81-112

50 Shu D G, Conway Morris S, Han J, et al. Head and backbone of the Early Cambrian vertebrate Haikouichthys. Nature, 2003, 421: 526-529 
51 Shu D G, Luo H L, Conway Morris S, et al. Lower Cambrian vertebrates from South China. Nature, 1999, 402: 42-46

52 Janvier P. Vertebrate characters and the Cambrian vertebrates. C R Palevol, 2003, 2: 523-531

53 Couly G F, Le Douarin N M. Mapping of the early neural primordium in quail-chick chimeras. I. Developmental relationships between placodes, facial ectoderm, and prosencephalon. Dev Biol, 1985, 110: 422-439

54 Treier M, Shawn O, Anatoli G, et al. Hedgehog signaling is required for pituitary gland development. Development, 2001, 128: 377-386

55 Kawamura K, Kouki T, Kawahara G, et al. Hypophyseal development in vertebrates from amphibians to mammals. Gen Comp Endocrinol, 2002, 126: 130-135

56 Gleiberman A S, Fedtsova N G, Rosenfeld M G. Tissue interactions in the induction of anterior pituitary: Role of the ventral diencephalon, mesenchyme, and notochord. Dev Biol, 1999, 213: 340-353

57 Zhao W J, Zhu M. Diversification and faunal shift of Siluro-Devonian vertebrates of China. Geol J, 2007, 42: 351-369

58 Forey P L, Janvier P. Agnathans and the origin of jawed vertebrates. Nature, 1993, 361: 129-134

59 Janvier P. The dawn of the vertebrates: Characters versus common ascent in the rise of current vertebrate phylogenies. Palaeontology, 1996, 39: 259-287

60 Donoghue P C J, Smith M P. The anatomy of Turinia pagei (Powrie), and the phylogenetic status of the Thelodonti. Trans R Soc Edinb Earth Sci, 2001, 92: 15-37

61 Gess R W, Coates M I, Rubidge B S. A lamprey from the Devonian period of South Africa. Nature, 2006, 443: 981-984

62 Wang $\mathrm{N}$ Z. Two new Silurian galeaspids (jawless craniates) from Zhejiang Province, China, with a discussion of galeaspid-gnathostome relationships. In: Chang M M, Liu Y H, Zhang G R, eds. Early Vertebrates and Related Problems of Evolutionary Biology. Beijing: Science Press, 1991. 41-66

63 Damas H. Recherches sur le développement de Lampetra fluviatilis L. Contribution a l'étude de la céphalogenese de Vertébrés. Arch Biol, 1944, 55: 1-285

64 Johnels A G. On the development and morphology of the skeleton of the head of Petromyzon. Acta Zool, 1948, 29: 139-279

65 Jollie M. Chordate Morphology. New York: Reinhold Books, 1962. 1-478

66 de Beer G R. The Development of the Vertebrate Skull. Oxford: Oxford University Press, 1937 